\author{
S. Abildina ${ }^{1 *}$, K. Kopbalina ${ }^{2}$, V. Musina ${ }^{3}$, A. Beisenbayeva ${ }^{4}$ \\ ${ }_{1,2,3,4}$ Karagandy university of the name of academician E.A.Buketov, Kazakhstan \\ (Corresponding author's e-mail: salta-7069@mail.ru) \\ Scopus authors ID: $56128026400^{1}, 56167615600^{2}, 511954734884$
}

\title{
Features of assessment of primary school students in the context of updated educational content
}

\begin{abstract}
The article discusses the issue of transition of Kazakhstan secondary education to the updated content, reveals the main categories of the updated assessment system: assessment, criterial assessment, formative assessment. One of the goals of assessment is the formation and maintenance of students' motivation for purposeful learning. The introduced criterion assessment system is aimed at developing a student, increasing his motivation to learn. The role of formative assessment, evaluation criteria, feedback for each student and his parents becomes important. The authors formulate a number of features of the introduction of formative evaluation of the learning outcomes of primary school students. The article presents the results of a survey to identify the level of educational motivation of pupils in primary classes in the context of the implementation of criterion assessment. Based on a theoretical analysis of the sources, the results of the survey, the authors draw conclusions. The authors emphasize that the formative assessment conducted in primary school is aimed at working with each student, identifying the achievements of younger students and determining the level of skills and abilities, as well as systematically measuring the educational progress of students, which allows them to more accurately and objectively evaluate the achievements of each child. promotes the growth of the child, taking into account the interests and abilities of the student.
\end{abstract}

Keywords: assessment, criterion assessment, formative assessment, summative assessment, assessment criteria, learning outcomes, feedback, content of education.

\section{Introduction}

The development of modern society is accompanied by significant transformations in all areas of activity. Modernization of the modern education system accordingly requires changes in the content and quality of training of specialists of all levels, updating forms, methods and technologies of training.

In the Address of the President to the people of Kazakhstan N.A. Nazarbayev noted that the system and teaching methods of Nazarbayev Intellectual Schools should become a unified standard for public schools. This will be the final stage in the reform of school education. The knowledge assessment system should be based on international standards [1].

To this end, in Kazakhstan over the past five years, programs have been developed based on an updated standard for educational content. Since September 2015, the Program for updating the content of primary education has been successfully tested in 30 pilot schools, which include urban, rural and small schools. The approbation of educational programs brought positive learning results, and since September 2016, in all secondary schools of Kazakhstan in the first grades, a transition to an updated standard for the content of education was made [2].

A distinctive feature of updating the content is not the amount of students' knowledge on individual topics, but the real learning outcomes, as well as the skills and abilities of students to apply their knowledge in real situations. At the same time, the main task of the teacher becomes the organization of such an educational space in which students switch to self-regulatory training.

In the framework of updating the content of education, an integrative approach is being implemented, which ensures the continuity of the content of education in curricula in subjects on the principle of «spirality», that is, each goal, topic of study after a certain academic period is reviewed repeatedly with a gradual deepening or complication of the volume of knowledge and skills.

The classification of the expected results according to Bloom's taxonomy: «knows», «understands», «applies», «analyzes», «synthesizes», «evaluates» ensures the unity of the research, cognitive, practical and emotional and aesthetic ways of understanding the world. In addition, it promotes the development of critical thinking skills (analysis, synthesis, evaluation). Interdisciplinary communication, a practical orientation, and a direct relationship between the content of academic subjects and real life contribute to the development of a holistic perception of environmental reality and functional literacy among students [3]. 
An analysis of the state of the Kazakhstan system for assessing student learning in comparison with other countries showed that the 5-point assessment system does not adequately reflect the real level of students' knowledge, but it is not a generally accepted world system. In most countries of the world, there is a wider grading scale: from 6 (Poland) to 100-point (Japan), which allows teachers to show the nuances in his educational activities, encourages the student to try.

The main goal of the education system is to create conditions for the development of students. To achieve academic independence, initiative and responsibility of a primary school student, the control and evaluation independence of the child is of particular importance, that is, the ability to independently monitor and evaluate their activities, the activities of classmates, to identify and eliminate the causes of educational difficulties. The formation of this skill is ensured by the systematic use of formative assessment in everyday practice.

\section{Materials and Methods}

In our opinion, in the context of the transition to an updated educational content, the approach to assessing student achievement contributes to the positive overcoming of problems in learning, individualization of the educational process, increasing educational motivation, and the formation of students' selfregulation.

The main categories of the updated assessment system should be considered: assessment, criteria-based assessment, formative assessment, etc. It would be advisable to consider the content of these categories, presented by normative documents of the education system.

Criteria assessment is the process of correlating the learning outcomes actually achieved by students with the expected learning outcomes based on criteria developed.

Evaluation criteria are statements that allow teachers and students to recognize whether the learning objective has been achieved with formative assessment (success criteria), and statements that allow students to evaluate student performance in internal summative assessment [4].

In elementary school conditions, the objectivity of the marks given to students is determined by the evaluation criteria, which are conditionally divided into three groups:

1. A substantial group of assessment criteria implies completeness, generalization, systematicity, correctness, meaningfulness of knowledge, etc.

2. The activity group of criteria is aimed at assessing the strength, effectiveness of knowledge, mental operations, special subject, intellectual, general educational, research and other skills.

3 . The personal group of criteria includes the assessment of such personality traits as activity, independence, self-esteem, criticality, motivation for learning, etc. [5].

The above groups of assessment criteria are aimed at learning outcomes, which are a confirmed assessment of the amount of knowledge, skills, acquired, demonstrated to the student in mastering the educational program, and the formed values and attitudes.

In the framework of criteria-based assessment, summarized and formative (formative) assessment are distinguished.

Summary assessment - a type of assessment that is carried out at the end of a certain academic period (quarter, trimester, academic year), as well as the study of sections in accordance with the curriculum.

Summative assessment involves the collection of information to provide teachers, students and parents about the progress of students at the completion of sections, cross-cutting topics of the curriculum, a specific educational period with scoring and grades.

This type of assessment allows you to determine the level of assimilation of the content of the curriculum for a certain period and use the information obtained from the results of summative assessment for planning, correction and analysis of the learning process. The total work of students and the portfolio are a means of fixing, accumulating and evaluating the individual achievements of the student in a certain period of his education, which can help in determining the direction of development of students, with advice from teachers and other specialists.

Formative assessment - a type of assessment that determines the current level of knowledge and skills formation of students in everyday work in the lesson, at home and provides an operational relationship between the student and the teacher during the training, allows students to understand the degree of correctness of the assignment during the study of new material, to achieve goals training [6].

In the study of theoretical principles, we determined that the purpose of formative assessment is to adjust the activities of teachers and students in the learning process based on intermediate results. In one of the 
studies [7] in the field of teaching and learning, the original «black box» metaphor is used. Accordingly, the use of assessment for training has become known as "work inside the black box». This study showed that improving learning through assessment depends on key factors: goal setting, feedback, assessment, and posing questions.

The primary education phase is characterized by the main points:

- adoption and mastering by the child of the new social role of the student;

- the formation of the internal position of the student;

- the formation of the student's basics of the ability to learn and the ability to organize their activities.

- the child's self-esteem acquires the features of adequacy and reflexivity.

Children of primary school age should develop a focused and motivated activity of the student, aimed at mastering the learning activity, the basis of which is the formation of a stable system of educational, cognitive and social motives and the personal meaning of learning. Formation in the primary grades of motivation gives the child further meaningful meaning, since his own educational activity becomes for him a vital goal, and not just a means to achieve other goals. It is important to ensure that the formation of motivation that would support the effective and fruitful academic work of each student has become the basis for selfimprovement in the future. In this regard, the requirements of the new education standards provide for the distribution of social responsibility for learning outcomes between educational organizations, parents of students and society as a whole.

In traditional assessment, there are no clear criteria for assessing the achievement of learning outcomes that are understandable to students, parents and teachers. There is no operational connection between the student and teacher in the learning process, which does not contribute to the motivation of students to learn.

This fact is confirmed by the results of our survey, aimed at identifying the educational motivation of students in grade 3, in whose training criteria-based assessment is not used.

The survey results showed a different degree of severity of students' motivation to acquire knowledge. Only $16 \%$ of respondents are characterized by a high degree of severity of motivation to acquire knowledge. They are dominated by intrinsic motivation - motivation associated not with external circumstances, but with the content and process of activity. Most of the respondents surveyed are characterized by an average degree of severity of educational motivation (52\%). In addition, the motivation of $32 \%$ of the children surveyed is more due to external motives, rather than the content or process of activity, that is, low.

In our opinion, this is due to the fact that, in the traditional assessment, teachers give marks based on the average level of knowledge of the class. In addition, the grades presented do not provide a clear picture of the assimilation of specific knowledge, skills in individual sections of the curriculum, and do not allow to determine the individual learning path of each individual.

Criteria assessment, in turn, allows you to develop criteria that contribute to obtaining quality results, thereby improving the quality of teaching and learning. In the context of criteria-based assessment, it is possible to build an individual learning path for each individual, taking into account his individual abilities and characteristics, as well as use a variety of approaches and assessment tools.

Students have the opportunity to use a variety of learning styles, types of mental activity, to know and understand the assessment criteria to predict their own learning outcomes. Pupils can participate in reflection, evaluating themselves and their peers. And most importantly - use knowledge to solve real problems, express different points of view, think critically.

Tasks of the criteria-based assessment system:

1. To expand the capabilities and functions of assessment in the educational process.

2. Create conditions for continuous self-improvement of students through the establishment of regular feedback.

3. Promote the formation of common standards, quality mechanisms and assessment tools.

4. Provide objective, continuous and reliable information.

We would like to dwell in more detail on the formative assessment of primary school students.

Formative assessment is also called assessment for learning, which is «the process of searching and interpreting data used by students and their teachers to determine the stage at which students are in the process of learning, the direction in which to develop, and establish how best to achieve the necessary level»[8].

Formative assessment, implemented in the elementary grades, is aimed at working with each student, systematic measurement of students' educational progress, which allows more accurately and objectively assess the achievements of each child, contributes to the growth of the child, taking into account the interests and abilities of the student. 
In order to improve the results of their training, it is necessary to respond to the feedback received, which, in turn, should determine the motivation and desire to act.

Feedback, in turn, is considered as a response, response, response of the teacher to any action of the student. Effective feedback should answer the questions:

- What stage is the student in?

- How will he achieve the result?

- What does the student need to work on to fill in the gaps?

In other words, feedback is the exchange of comments about specific actions, situations, issues that adjust the path to the learning goal.

In this regard, the role of regular feedback becomes clear, which is understandable for the student and his parents, which makes it possible to identify learning problems, timely adjust the learning process, and help achieve the best results.

\section{Results and Discussions}

To compare the level of educational motivation, we conducted a survey of primary school students, in the training of which various formative assessment techniques were applied:

1) techniques used by the teacher in the process of explaining the topic, performing group tasks by students: «Signals with the hand», «20 seconds», «Gallery», etc.

2) techniques related to asking clarifying questions: «Why? How? What if...?».

3) techniques related to intermediate work: tests, assignments, short essays,.

4) techniques related to individual tasks: written feedback, «Two stars and one wish», «Traffic light», «Index of a card for generalization», «One-minute essay», «Speech samples», «Three-minute pause», «Verbal assessment» quiz.

The results of the survey showed the following degree of severity of students' motivation to acquire knowledge. $71 \%$ of respondents are characterized by a high degree of severity of motivation to acquire knowledge, that is, internal motivation dominates - motivation associated with the content and process of educational activity, which indicates the willingness and ability to switch to self-education on the basis of educational and cognitive motivation.

An average level of educational motivation was demonstrated by $23 \%$ of students. The motivation of only $6 \%$ of the children surveyed is more due to external motives, rather than the content or process of activity.

Comparative results are shown in Figure 1.

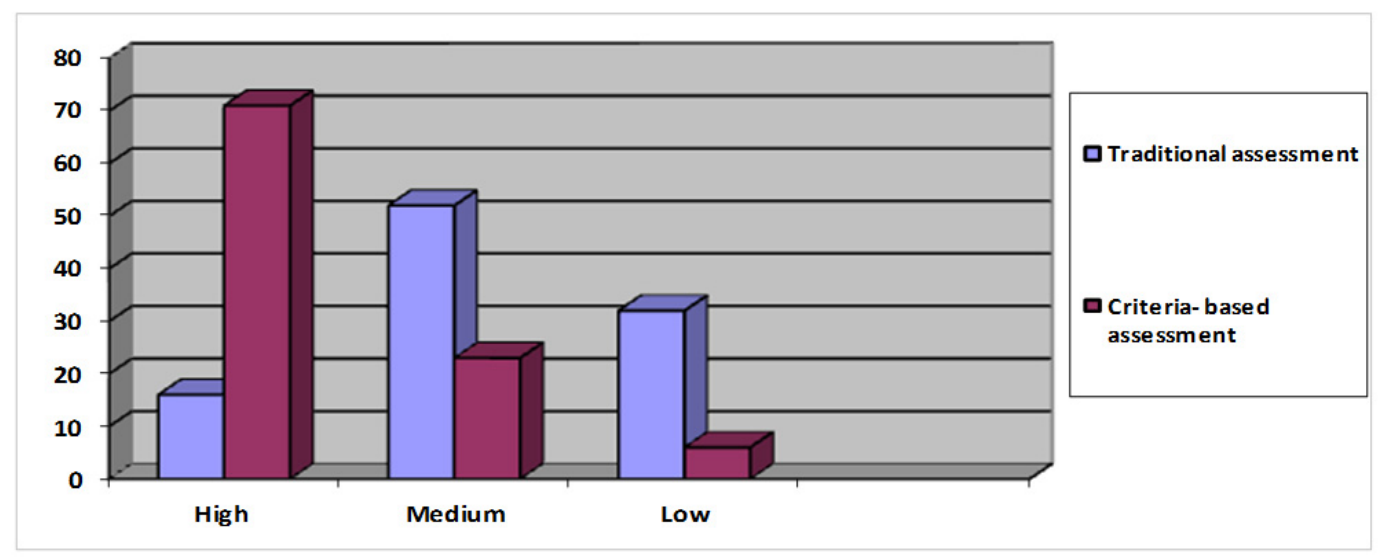

Figure 1. Comparative survey results

During observations of the introduction of criteria-based assessment techniques, we identified a number of features:

Verification work of primary school students should not cause alarm, but contribute to cognition. The teacher's task is to convey to the children the role of verification work as a means to determine what has been achieved and where teacher assistance is needed. Preliminary scoring of the criteria for evaluating work is required. 
Feedback with primary school students should be, above all, timely. Feedback should be provided to students as soon as possible after the verification work, which will help establish a student's trusting relationship with school.

In addition, the feedback must be correct. When providing feedback to students, positive aspects need to be discussed first, and negative feedback should be directed to the weaknesses of the work, and not to the student. It is also advisable to provide students with the opportunity to reflect on the cause of the mistakes made.

When providing comments, students should use such wordings and phrases of a recommendatory nature («your story will be even more interesting if you....). Offensive comments are not allowed.

\section{Conclusions}

Thus, the theoretical analysis of the sources, the results of the questionnaire, allowed us to draw the following conclusions.

- criteria-based assessment does not imply a process of competition between students or comparison of their educational achievements. As you know, in the traditional assessment, teachers are faced with a situation where parents do not agree with the assessment of the teacher, proving the discrepancy of the grade with the knowledge of their children.

- the fact of evaluating the educational activities of students according to predetermined criteria ensures transparency and accessibility for all participants in the educational process.

- each student has the opportunity to improve, reaching the level of their abilities according to specified criteria, and achieve the expected result in the subject.

- Using assessment criteria, students learn to design a path to achieve their goals, and at the same time learn to more objectively evaluate the quality of their work.

- it is important to systematically conduct a formative assessment with the provision of constructive feedback, since the results of a summative assessment depend on the quality of a formative assessment.

\section{References}

1 Message from the President of the Republic of Kazakhstan N. Nazarbayev to the people of Kazakhstan dated 10/05/2018 «Growing welfare of Kazakhstan people: improving income and quality of life». online.zakon.kz. Retrieved from http: online.zakon.kz/m/document/.

2 Abdildina J. (2016). Update - for effective and quality education // Bilimdi. An educated country. No. 15 (52) August 16. Retrieved from www.bilimdinews.kz.

3 Education Transformation, Assessment, and Teaching Skills Required in the 21st Century: Call to Action (Intel, Microsoft, and Cisco Education Group, September 1, 2008). cisco.com. Retrieved from http://www.cisco.com/web/RU/news/ releases/txt/2009 /011409d.html.

4 The state compulsory standard of secondary education with updated content. Approved by the Government of the Republic of Kazakhstan dated August 23, 2012 No. 1080. nao.kz. Retrieved from https://nao.kz/loader/fromorg/2/22.

5 The Law of the Republic of Kazakhstan dated July 27, 2007 No. 319-III «On Education». online.zakon.kz. Retrieved from https://online.zakon.kz/Document/? doc_id=30118747.

6 The state compulsory standard of primary education. Approved by the Government of the Republic of Kazakhstan dated August 23, 2012 No. 1080. nao.kz. Retrieved from https://nao.kz/loader/fromorg/2/22.

7 Black P., \& Wiliam D. Assessment for learning: Beyond the black box. — 1999.

8 Formative assessment in elementary school. A practical guide for the teacher / Comp. O.I. Dudkina, A.A. Burkitova, R.Kh. Shakirov. (2012). B.: Bilim.

\section{С. Әбілдина, К. Копбалина, В. Мусина, А. Бейсенбаева \\ Білім беру мазмұнын өзектендіру контексінде бастауыш сынып оқушыларын бағалау ерекшеліктері}

\footnotetext{
Мақалада қазақстандық орта білім берудің жаңартылған мазмұнға көшуі туралы мәселе қарастырылды, бағалаудың жаңартылған жүйесінің негізгі категориялары ашылған: бағалау, критериалды бағалау, қалыптастырушы бағалау. Бағалаудың негізгі мақсаттарының бірі қалыптастыру және мақсатқа бағытталған білім алуға оқушылардың мотивацияларын қолдау. Енгізілген критериалды бағалау жүйесі оқушылардың білім алуға деген мотивтерін жоғарлатуға бағытталған. Бағалау критерийлерінің ішінде қалыптастырушы бағалаудың рөлі маңызды болып
} 
табылады, яғни әрбір оқушы мен ата-аналары үшін кері байланыс. Авторлар бастауыш сынып окушыларының білім нәтижелеріне қалыптастырушы бағалауды енгізу ерекшеліктерін құрастырды. Мақалада критериалды бағалауды жүзеге асыру жағдайында бастауыш сынып оқушыларының оку мотивацияларының деңгейін анықтау бойынша жүргізілген сауалнама нәтижелері көрсетілген. Жүргізілген сауалнама нәтижелеріне теориялық талдау көздерінің негізінде қорытынды жасалған. Авторлардың есептеулерінше, бастауыш сыныптарға жүргізілген қалыптастырушы бағалау нәтижесінде әрбір оқушымен жеке жұмыс жасауға бағытталған, кіші мектеп оқушыларының жетістіктері және дағды, іскерліктерінің қалыптастыру деңгейлері анықталған, сонымен қатар оқушылардың білім алуының ілгерлеуін жүйелі өлшеуге негізделеді, ол әрбір оқушының жетістігін айқын бағалауға, баланың қызығушылығы мен қабілетін ескере отырып дамуына, мүмкіндік береді.

Кілт сөздер: бағалау, критериалды бағалау, қалыптастырушы бағалау, суммативті бағалау, бағалау критерийлері, білім нәтижелері, кері байланыс, білім беру мазмұны.

\author{
С. Абильдина, К. Копбалина, В. Мусина, А. Бейсенбаева
}

\title{
Особенности оценивания учащихся начальных классов в контексте актуализации содержания образования
}

В статье рассмотрен вопрос о переходе казахстанского среднего образования на обновленное содержание, раскрыты основные категории обновленной системы оценивания: оценивание, критериальное и формативное оценивание. Одной из целей оценивания является формирование и поддержание мотивации учащихся к целенаправленному учению. Внедряемая система критериального оценивания направлена на развитие учащегося, повышение его мотивации к обучению. Важной становится роль формативного оценивания, критериев оценивания, обратной связи для каждого ученика и его родителей. Авторы формулируют ряд особенностей внедрения формативного оценивания результатов обучения учащихся начальных классов. В статье представлены результаты анкетирования по выявлению уровня учебной мотивации учащихся начальных классов в условиях реализации критериального оценивания. На основе теоретического анализа источников, результатов проведенного анкетирования авторами сделаны определенные выводы. Они считают, что формативное оценивание, проводимое в начальных классах, направлено на работу с каждым учеником, выявление достижений младших школьников и определение уровня сформированности навыков, умений, а также систематическое измерение образовательного прогресса учащихся, которое позволяет более точно и объективно оценивать достижения каждого ребенка, способствует росту ребенка, учитывая интересы и способности ученика.

Ключевые слова: оценивание, критериальное оценивание, формативное оценивание, суммативное оценивание, критерии оценивания, результаты обучения, обратная связь, содержание образования. 